\title{
Some deep-water cheilostome Bryozoa from the south coast of South Africa
}

\author{
Wayne K. Florence \\ Natural History Collections Department, Iziko Museums of South Africa, P.O. Box 61, Cape Town, 8000 South Africa \\ E-mail:wflorence@iziko.org.za \\ (with 1 figure and 1 table) \\ Received 16 May 2014. Accepted 30 November 2015
}

\begin{abstract}
Twelve species of deep-water cheilostome Bryozoa are reported from an incidental deep-water collection from the south coast of South Africa. The collection represents nine families and ten genera. One species, Arthropoma lioneli sp. nov., is new to science. The results reinforce the need for targeted sampling of South Africa's poorly known deep-water benthic fauna to assist the assignment of offshore marine protected areas within its Exclusive Economic Zone. With the addition of the new species, the bryozoan fauna of South Africa comprises no fewer than 27 I valid marine species.
\end{abstract}

Key words: Bryozoa, Cheilostomata, new species, deep-water, benthic, taxonomy.

\section{CONTENTS}

\begin{tabular}{|c|c|c|}
\hline Abstract $\ldots \ldots \ldots \ldots \ldots \ldots$ & Genus Menipea . . . . . . . . . . . . & Family Petraliellidae $\cdots \cdots \cdots$ \\
\hline Introduction . . . . . . . . . . . 5 & Family Aspidostomatidae . . . . . . & Genus Mucropetraliella . . . . . . . 8 8 \\
\hline Materials and methods $\ldots \ldots \ldots$ & Genus Aspidostoma . . . . . . . . . & Family Lacernidae . . . . . . . 8 \\
\hline Systematics . . . . . . . . . . . 5 & Family Adeonellidae . . . . . . . . . & Genus Arthopoma . . . . . . . . . . . . . \\
\hline Order Cheilostomata $\ldots \ldots \ldots$ & Genus Adeonella . . . . . . . . . . . . & Family Phidoloporidae . . . . . . \\
\hline Suborder Neocheilostomina & Family Romancheinidae . . . & Genus Schizoretepora … . . \\
\hline Family Calloporidae $\ldots \ldots$. & Genus Escharoides . . . . . & Genus Reteporella ... \\
\hline Genus Amphiblestrum & Family Microporellidae. & Acknowledgements \\
\hline Family Candidae . . . & Genus Flustramorpha . . & References . . . . . . \\
\hline
\end{tabular}

\section{INTRODUCTION}

Previous studies on the deep-water $(80-1300 \mathrm{~m})$ bryozoan fauna by Hayward \& Cook $(1979,1983)$ have revealed a remarkable diversity of no fewer than 159 species reported from the collections of the South African Museum's Meiring Naudé cruises of the late 1970s. The very low-effort collection reported on here revealed 12 species, one of which, Arthropoma lioneli sp. nov., is new to science. These findings reaffirm the need for targeted deep-water sampling of benthic bryozoans in order to reveal the potential regional diversity of this phylum. The focus of future surveys should be directed at the south and west coasts of South Africa where there is a paucity of knowledge of bryozoans. Following the remarkable discoveries made by Hayward \& Cook $(1979,1983)$ future targeted work in this region is expected to yield significantly new knowledge of the deep-water fauna.

\section{MATERIALS AND METHODS}

General methods closely follow those of Florence et al. (2007). Byozoan specimens were collected from by-catch of one bottom-trawled station (ANO183 - $35^{\circ} 40^{\prime} \mathrm{S}, 22^{\circ} 53^{\prime} \mathrm{E}$, depth $95 \mathrm{~m}$ ) along the south coast of South Africa during a survey of the Dr Fritjov Nansen (a demersal trawler) during May 2000. Only species that were not described in Florence et al. (2007) are here fully described and figured from the current material as all others agreed closely with the descriptions of conspecific species provided by those authors. All material has been deposited in the collections of the Natural History Collections Department, Iziko Museums of South Africa, Cape Town. Catalogue numbers are provided in the 'material examined' sections below. The following abbreviations are used for the tabulated measurements of Arthropoma lioneli sp. nov.: autozooid length (Lz), autozooid width (lz), orifice length (Lso), orifice width (lso), ovicell length (Lov) and ovicell width (lov).

\section{SYSTEMATICS}

Order CHEILOSTOMATA Busk, 1852

Suborder NEOCHEILOSTOMINA d'Hondt, 1985

Family CALLOPORIDAE Norman, 1903

Genus Amphiblestrum Gray, 1848

Amphiblestrum triangularis (O'Donoghue, 1924)

Lepralia triangularis O'Donoghue, 1924: 43, pl. 2, figs 11-12; O'Donoghue \& de Watteville 1944: 424.

Amphiblestrum triangularis O'Donoghue, 1957: 74; Florence et al. 2007: 12, figs 4A-B. 
Amphiblestrum inermis Hayward \& Cook, 1983: 12, fig. 1D-F. not Membranipora inermis Kluge, 1914: 663, pl. 34 fig. 6.

\section{Material examined}

Current material: SAMC-A28657, station ANO183 $\left(33^{\circ} 56^{\prime} \mathrm{S}, 18^{\circ} 22^{\prime} \mathrm{E}\right)$, depth $95 \mathrm{~m}$, collected by G. Harkins, 30 May 2000. Other material: SAMC-A28569, Bakoven (33 $\left.56^{\prime} \mathrm{S}, 18^{\circ} 22^{\prime} \mathrm{E}\right)$, depth $8 \mathrm{~m}$, collected by W. Florence, 5 May 1999.

\section{Remarks}

The confused synonomy of Amphiblestrum triangularis (O'Donoghue, 1924) with $A$. inermis (Kluge, 1914) was resolved by Florence et al. (2007). The current specimens agree closely with a specimen from Bakoven (SAMC-A28569) described by Florence et al. (2007).

\section{Family CANDIDAE d'Orbigny, 1851}

\section{Genus Menipea Lamouroux, 1812}

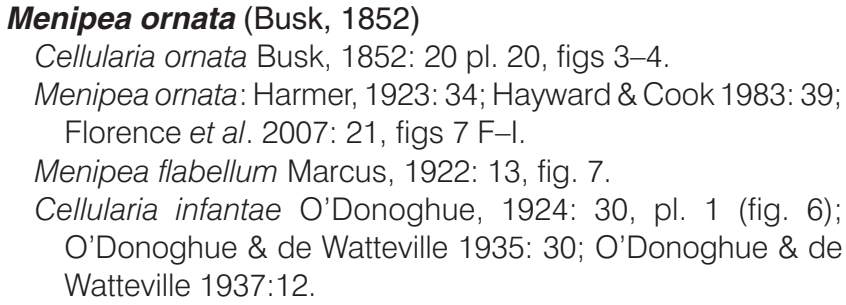

\section{Material examined}

Current material: SAMC-A28658, station ANO183 (33 ${ }^{\circ} 56$ 'S, $\left.18^{\circ} 22^{\prime} \mathrm{E}\right)$, depth $95 \mathrm{~m}$, collected by G. Harkins, 30 May 2000. Other material: SAMC-A28588, Justin's Caves, Oudekraal ( $\left.33^{\circ} 58^{\prime} 90^{\prime \prime} \mathrm{S}, 18^{\circ} 20^{\prime} 65^{\prime \prime} \mathrm{E}\right)$, depth $15 \mathrm{~m}$, collected by W. Florence, 24 April 1999. SAMC-A28589, Homestead Plateau, Oudekraal ( $\left.33^{\circ} 58^{\prime} 90^{\prime \prime} \mathrm{S}, 18^{\circ} 21^{\prime} 30^{\prime \prime} \mathrm{E}\right)$, depth $10 \mathrm{~m}$, collected by W. Florence, 30 April 1999.

\section{Remarks}

The confused synonomy associated with this species has been cleared up by Hastings (1943: 332). The current specimens agree closely with specimens from Oudekraal (SAMC-A28588, SAMC-A28589) described by Florence et al. (2007).

\section{Menipea marionensis Busk, 1884}

Menipea marionensis Busk, 1884: 21, pl. 4, figs 3, 3a; Harmer 1923: 341, pl. 17, fig. 22; pl. 19 figs 43-45. Hayward \& Cook 1983: 40. Florence et al. 2007: 23, figs 8E-I.

\section{Material examined}

Current material: SAMC-A28659, station ANO183 (33 $56^{\circ}$ 'S, $\left.18^{\circ} 22^{\prime} \mathrm{E}\right)$, depth $95 \mathrm{~m}$, collected by G. Harkins, 30 May 2000. Other material: SAMC-A28655, Castle Rock, False Bay $\left(34^{\circ} 14^{\prime} \mathrm{S}, 18^{\circ} 29^{\prime} \mathrm{E}\right)$, depth $15 \mathrm{~m}$, collected by G. Isaacs, 2 March 2000.

\section{Remarks}

This species is very similar to Menipea triseriata but differs from it by having a more prominent gymnocyst, one distolateral spine per outer zooid and nine zooids per internode as opposed to 15 . The current specimens agree closely with a specimen from False Bay (SAMC-A28655) described by Florence et al. (2007).

Family ASPIDOSTOMATIDAE Jullien, 1888

Genus Aspidostoma Hincks, 1881

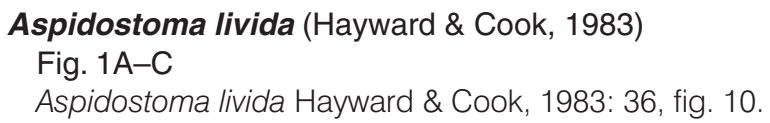

Material examined

Current material: SAMC-A28660, station ANO183

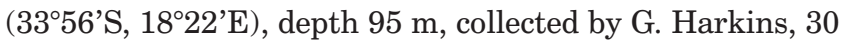
May 2000.

\section{Description}

Colony erect, bilaminar and reticulate, forming broad plates. Deep blue-grey in colour when alive and when dried. Fenestrulae long and oval occurring frequently throughout the colony. Autozooids large and hexagonal, convex, frontal surface granular and separated by distinct grooves. Frontal wall convex but becoming concave towards the opesia; proximal edge of opesia with thick 'axehead-shaped' lip with thick median edge extending proximally from it. Distal end of zooid raised as a prominent hood. Ovicell globose, flattened frontally and coarsely granular; opening via a hooded aperture located distal to the zooid operculum. Vicarous avicularia sparsely scattered over the colony; rostrum acute triangular and directed distolaterally. No spines were observed.

\section{Substratum, depth range and ecology}

May be found encrusting rocks and stones in sublittoral waters. The older or worn parts of the colony usually colonized by other bryozoans and entoprocts. Depth range: 95-700 m.

\section{Geographic distribution}

This species has been reported only from South Africa and is distributed from deeper waters of Mossel Bay to the Wild Coast along the South African coastline.

\section{Remarks}

This species is easily identified and is unique from other congeneric species in that the only other erect species of Aspidostoma develop cylindrical colonies as opposed to the reticulate anastomosing form of the current specimen. The specimen is consistent with the description and figured specimen of Hayward \& Cook (1983).

Family ADEONELLIDAE Gregory, 1893

Genus Adeonella Busk, 1884

Adeonella pluscula Hayward, 1988

Adeonella pluscula Hayward, 1988: 181, fig. 28A-D; Florence et al. 2007: 12, fig. 4A-B.

Material examined

Current material: SAMC-A28661, station ANO183 

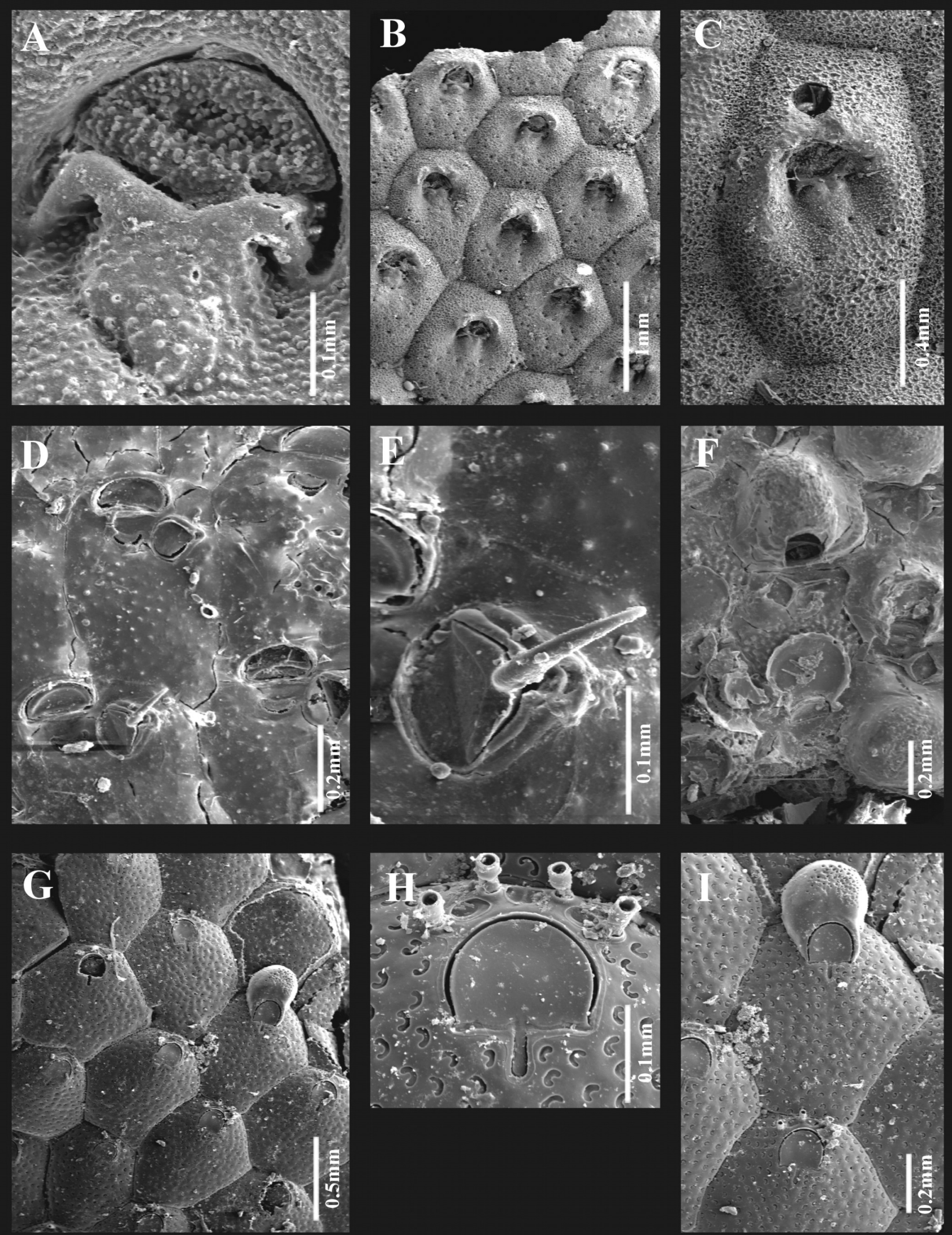

Fig. 1. A-C, Aspidostoma livida (Hayward \& Cook, 1983). D-F, Flustramorpha marginata (Krauss, 1837). G-I, Arthopoma lioneli sp. nov. (SAMC-A28665). 
$\left(33^{\circ} 56^{\prime} \mathrm{S}, 18^{\circ} 22^{\prime} \mathrm{E}\right)$, depth $95 \mathrm{~m}$, collected by G. Harkins, 30 May 2000. Other material: SAMC-A28609, A-Frame, False Bay ( $\left.34^{\circ} 13^{\prime} \mathrm{S}, 18^{\circ} 28^{\prime} \mathrm{E}\right)$, depth $12 \mathrm{~m}$, collected by W. Florence, 12 March 2000. SAMC-A28610, Justin's Caves, Oudekraal ( $\left.33^{\circ} 58^{\prime} 90^{\prime \prime} \mathrm{S}, 18^{\circ} 20^{\prime} 65^{\prime \prime} \mathrm{E}\right)$, depth $15 \mathrm{~m}$, collected by G. Isaacs, 24 April 1999

\section{Remarks}

Adeonella pluscula was first described by Hayward (1988). He noted that the branches of this colony are very broad at the growing margins and consist only of autozooids and gonozooids whereas the lateral edges of the branches consist only of avicularia and kenozooids. The current specimens agree closely with descriptions in Hayward (1988) and specimens from False Bay (SAMC-A28609) and Oudekraal (SAMC-A28610) described by Florence et al. (2007).

Family ROMANCHEINIDAE Jullien, 1888

\section{Genus Escharoides Milne Edwards, 1836}

\section{Escharoides contorta Busk, 1854}

Escharoides contorta Busk, 1854: 89, pl. 108, figs 1-3; O'Donoghue 1957: 88, figs 10-11; Hayward \& Cook 1983: 47.

Mucronella contorta: Busk 1884: 155, pl. 20, fig. 9; O'Donoghue \& de Watteville 1937: 18.

Material examined

Current material: SAMC-A28662, station ANO183 $\left(33^{\circ} 56^{\prime} \mathrm{S}, 18^{\circ} 22^{\prime} \mathrm{E}\right)$, depth $95 \mathrm{~m}$, collected by G. Harkins, 30 May 2000. Other material: SAMC-A28618, Homestead Plateau, Oudekraal ( $\left.33^{\circ} 58^{\prime} 90^{\prime \prime} \mathrm{S}, 18^{\circ} 21^{\prime} 30^{\prime \prime} \mathrm{E}\right)$, depth $12 \mathrm{~m}$, collected by W. Florence, 30 April 1999.

\section{Remarks}

Although the current specimen is very worn and collected from the seabed in the region of fragments of other dead colonies it is easily recognizable as Escharoides contorta. This species is most similar to E. distincta (Hayward \& Cook, 1979) but differs from it in the orientation of the oral spines and the morphology of the proximal-median lip. The current specimen agrees closely with a specimen from Oudekraal (SAMC-A28618) described by Florence et al. (2007).

Family MICROPORELLIDAE Hincks, 1879

Genus Flustramorpha Gray, 1872

\section{Flustramorpha marginata (Krauss, 1837)}

Fig. 1D-F

Flustra marginata Krauss, 1837: 35, fig. 3.

Flustramorpha marginata Busk, 1884: 135, pl. 20, fig. 8; Hayward \& Cook 1979: 80; Hayward \& Cook 1983: 84, fig. 20B-C

\section{Material examined}

Current material: SAMC-A28663, station ANO183 $\left(33^{\circ} 56^{\prime} \mathrm{S}, 18^{\circ} 22^{\prime} \mathrm{E}\right)$, depth $95 \mathrm{~m}$, collected by G. Harkins, 30 May 2000.

\section{Description}

Colony erect, bilaminar and foliaceous. Light brown when alive and dark yellow when dry. Autozooids are hexagonal, broad and flat, arranged multiserially alternating; sepa- rated by distinct raised sutures. Primary orifice semicircular with distinct lateral condyles. Frontal shield granular with numerous small pores and a medially positioned, crescentic ascopore. Avicularium adventitious and positioned proximolaterally to the orifice; rostrum oval with a long setiform mandible. Ovicell prominent.

\section{Substratum, depth range and ecology}

Lives erect on hard substrata. Depth range: 80-450 m.

\section{Geographic distribution}

This species has been reported only from South Africa and is distributed from offshore of Mossel Bay to Sodwana Bay.

\section{Remarks}

Hayward \& Cook (1983) pointed out the difficulties in distinguishing between Flustramorpha species. F. marginalis is most similar to F. flabellaris (Busk, 1854) and F. angusta (Hayward \& Cook, 1979). F. marginalis has avicularia with long setiform mandibles and a palate that is orientated at anoblique, or perpendicular, angle to the frontal plane as opposed to short acuminate mandibles and a parallel palate in F. flabellaris. F. angusta has a proportionally small, narrower and depressed ovicell, which is progressively obscured by secondary calcification, and a semi-elliptical orifice with a straight proximal border that distinguishes it from F. marginalis.

Family PETRALIELLIDAE Harmer, 1957

Genus Mucropetraliella Stach, 1936

Mucropetraliella asymmetrica Hayward \& Cook, 1983

Mucropetraliella asymmetrica Hayward \& Cook, 1983: 67, fig. 18.

\section{Material examined}

Current material: SAMC-A28664, station ANO183 ( $\left.33^{\circ} 56^{\prime} \mathrm{S}, 18^{\circ} 22^{\prime} \mathrm{E}\right)$, depth $95 \mathrm{~m}$, collected by G. Harkins, 30 May 2000. Other material: SAMC-A28644 A-Frame, False Bay ( $\left.34^{\circ} 13^{\prime} \mathrm{S}, 18^{\circ} 28^{\prime} \mathrm{E}\right)$, depth $15 \mathrm{~m}$, collected by W. Florence, 12 March 2000.

\section{Remarks}

This species was first described by Hayward \& Cook (1983), who discussed its similarities to M. watersi (Harmer, 1957). The current specimen agrees closely with Hayward \& Cook's (1983) description as well as the type specimen and is easily recognizable. This record represents the most western occurrence of $M$. asymmetrica at rather a shallow depth, suggesting that this species has a wider bathymetric and geographic range than previously thought.

Family LACERNIDAE Jullien, 1888

Genus Arthopoma Levinsen, 1909

Arthopoma lioneli sp. nov.

Fig. 1G-I, Table 1

Arthropoma sp. Hayward \& Cook 1983: 70, fig. 17D.

\section{Etymology}

Honorific for my late father, Lionel Florence, who passed 
Table 1. Measurements (in millimetres) of Arthropoma lioneli sp. nov. material.

\begin{tabular}{lcccc}
\hline & $n$ & $\bar{x}$ & S.D. & Range \\
\hline Lz & 20 & 1.01 & 0.09 & $0.89-1.20$ \\
Iz & 20 & 0.93 & 0.19 & $0.60-1.34$ \\
Lso & 20 & 0.16 & 0.02 & $0.14-0.18$ \\
Iso & 20 & 0.18 & 0.01 & $0.16-0.20$ \\
Lov & 10 & 0.39 & 0.01 & $0.37-0.40$ \\
lov & 10 & 0.46 & 0.03 & $0.43-0.52$ \\
\hline
\end{tabular}

away during the drafting of this manuscript and who deserves any credit that this work earns.

\section{Material examined}

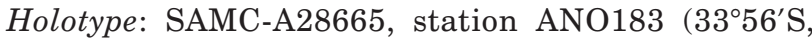
$\left.18^{\circ} 22^{\prime} \mathrm{E}\right)$, depth $95 \mathrm{~m}$, collected by G. Harkins, 30 May 2000.

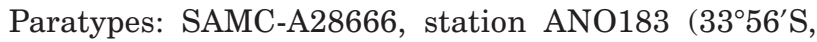
$\left.18^{\circ} 22^{\prime} \mathrm{E}\right)$, depth $95 \mathrm{~m}$, collected by G. Harkins, 30 May 2000.

Voucher material: Arthropoma lioneli determined as Arthropoma sp. by Hayward \& Cook (1983): SAMC-A26845, station SM163 $\left(33^{\circ} 04.6^{\prime} \mathrm{S}, 2^{\circ} 06.6^{\prime} \mathrm{E}\right)$, depth $90 \mathrm{~m}$, collected by SAM Meiring Naudé, 26 May 1978; SAMC-A26763,

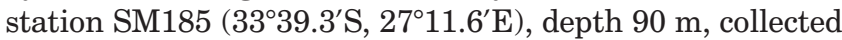
by SAM Meiring Naudé, 31 May 1978;

Other material: Arthropoma cecilii: SAMC-A26611, station SM185 (33 $\left.39.3^{\prime} \mathrm{S}, 2^{\circ} 11.6^{\prime} \mathrm{E}\right)$, depth $90 \mathrm{~m}$, collected by SAM Meiring Naudé, 31 May 1978; BMNH 97.5.1.730, Port Phillip Heads, Australia. Phonicosia circinata determined as Arthropoma circinatum by Hayward \& Cook (1983): BMNH 1983.11.5.49, station SM163 (3304.6' S, $\left.28^{\circ} 06.6^{\prime} \mathrm{E}\right)$, depth $90 \mathrm{~m}$, collected by SAM Meiring Naudé, 26 May 1978.

\section{Description}

Colony encrusting unilaminar; forming irregular patches. White when alive and when dry. Autozooids hexagonal and convex; separated by distinct grooves (ca. $1.01 \times 0.93 \mathrm{~mm}$ ). Frontal shield smooth, perforated by numerous small kidney-shaped pores, becoming less distinct in later ontogeny; indistinct imperforate ridge below the primary orifice but not sufficiently developed to be considered an umbo. Primary orifice with D-shaped poster, slightly wider than long (ca. $0.16 \times 0.18 \mathrm{~mm}$ excluding sinus), proximal border straight and indented medially by a deep, narrow, sinus that is approximately longer than half the length of the poster; condyles thick, smooth, rounded towards each other thereby narrowing the entrance of the sinus. Three to six distal oral spines present. Ovicell prominent, globular and wider than long; frontal surface slightly granular and one distinct spine base on either side, distolateral, of the primary orifice. No avicularia observed.

\section{Substratum, depth range and ecology}

Forms thick encrustations on mollusc shells. Depth range: 80-95 m.

\section{Geographic distribution}

This species is known only from South Africa and has a south-coast distribution range from False Bay to Port Alfred.

\section{Remarks}

Arthropoma is a small genus of lacernid Bryozoa that previously comprised just two valid recent species; $A$. cecilii (Audouin, 1826) and A. inarmata Gontar, 1993. The latter has been reported only from the Kuril Islands in Russia (Gontar, 1993). While A. cecilii has a known warmtemperate to circumtropical distribution; it has also previously been reported from South Africa by Hayward \& Cook (1983). In addition, these authors also reported on two other species from South Africa; A. circinatum (MacGillivray, 1869) and an unnamed species, Arthropoma sp. During the current study a re-examination of Hayward and Cook's specimens supports the synonomic treatment of $A$. circinatum (BMNH 1983.11.5.49) with Phonicosia circinata (MacGillivray, 1869), in accordance with Gordon (1984). Examination of the fragmentary specimens of Arthropoma sp. Hayward \& Cook 1983 (SAMC-A26845, SAMC-A26763), reveals that it is consistent in all discernible characters with the current specimens and is herein synonomized with A. lioneli sp. nov.

The narrow slit-like oral sinus, small kidney shaped frontal pores and the presence of oral spines primarily distinguishes Arthropoma lioneli sp. nov. from all other Arthopoma species; A. cecilii and A. inarmata posses a wide or U-shaped oral sinus and round frontal pores, and lack oral spines. A. lioneli sp. nov. has larger, more hexagonal, autozooids than both $A$. cecilii $(0.7-0.8 \times 0.4-0.6 \mathrm{~mm})$ and A. inarmata $(0.8-0.1 \times 0.52-0.60 \mathrm{~mm})$. In addition, $A$. lioneli also differs from $A$. cecilii as its condyles are rounded towards each other rather than being flat and its ovicell frontal wall is not tessellate but rather only finely granular. The above-mentioned differences are herein considered sufficient to warrant the erection of $A$. lioneli sp. nov.

Family PHIDOLOPORIDAE Gabb \& Horn, 1862

\section{Genus Schizoretepora Gregory, 1893}

\section{Schizoretepora tessellata (Hinks, 1878)}

Retepora tessellata Hinks, 1878: 358, pl. 19, figs 9-12; Busk 1884: 112, pl. 27, fig. 8; O'Donoghue \& de Watteville 1935: 210; O'Donoghue \& de Watteville 1937: 15; O'Donoghue 1957: 91.

Schizoretepora tessellata: Hayward \& Cook 1983: 106, fig. $24 \mathrm{H}$.

\section{Material examined}

Current material: SAMC-A28667, station ANO183 ( $\left.33^{\circ} 56^{\prime} \mathrm{S}, 18^{\circ} 22^{\prime} \mathrm{E}\right)$, depth $95 \mathrm{~m}$, collected by G. Harkins, 30 May 2000. Other material: SAMC-A28648 A-Frame, False Bay ( $\left.34^{\circ} 13^{\prime} \mathrm{S}, 18^{\circ} 28^{\prime} \mathrm{E}\right)$, depth $15 \mathrm{~m}$, collected by G. Isaacs, 12 March 2000; SAMC-A28649 Homestead Plateau, Oudekraal ( $\left.33^{\circ} 58^{\prime} 90^{\prime \prime} \mathrm{S}, 18^{\circ} 21^{\prime} 30^{\prime \prime} \mathrm{E}\right)$, depth $12 \mathrm{~m}$, collected by G. Isaacs, 30 April 1999; SAMC-A28650 Justin's Caves, Oudekraal ( $\left.33^{\circ} 58^{\prime} 90^{\prime \prime} \mathrm{S}, 18^{\circ} 20^{\prime} 65^{\prime \prime} \mathrm{E}\right)$, depth $18 \mathrm{~m}$, collected by G. Isaacs, 24 April 1999.

\section{Remarks}

This species is extraordinary in terms of its variable colony morphology. It is either unilaminar and fenestrate or bilaminar and sheet-like, or both in the same colony, with fenestrulae present at the growing edge. Hayward \& Cook 
(1983) noted that there is variability in the width of the primary orifice in various specimens from Australia and South Africa. This was also noted in the current specimens. Furthermore the Australian specimens developed long $(0.8 \mathrm{~mm})$ antenniform spines, whereas the present specimens from South Africa appear to have consistently shorter spines (mean $=0.5 \mathrm{~mm}, n=20$ ). The avicularia and ovicells appear to be consistent with the specimens of Hayward \& Cook (1983) and therefore also with the Australian specimens.

\section{Genus Reteporella Busk, 1884}

Reteporella lata (Busk, 1884)

Sertella lata Busk, 1884: 115, pl. 27, fig. 1; Hayward \& Cook 1983: 105, fig. 24F-G.

\section{Material examined}

Current material: SAMC-A28668, station ANO183 $\left(33^{\circ} 56^{\prime} \mathrm{S}, 18^{\circ} 22^{\prime} \mathrm{E}\right)$, depth $95 \mathrm{~m}$, collected by G. Harkins, 30 May 2000. Other material: SAMC-A28651 Homestead Plateau, Oudekraal $\left(33^{\circ} 58^{\prime} 90^{\prime \prime} \mathrm{S}, 18^{\circ} 21^{\prime} 30^{\prime \prime} \mathrm{E}\right)$, depth $12 \mathrm{~m}$, collected by G. Isaacs, 30 April 1999; SAMC-A28652 Justin's Caves, Oudekraal $\left(33^{\circ} 58^{\prime} 90^{\prime \prime} \mathrm{S}, 18^{\circ} 20^{\prime} 65^{\prime \prime} \mathrm{E}\right)$, depth $18 \mathrm{~m}$, collected by W. Florence, 24 April 1999.

\section{Remarks}

Hayward \& Cook (1983) defined the most characteristic feature of Reteporella lata to be the pear-shaped ovicell with its long labellum. These authors suggest that Busk (1884) missed this in his illustration of the type specimen of $R$. lata, but upon re-examination they found that the type was consistent with their Meiring Naudé specimens. The present specimens in this study are consistent with those of the above-mentioned works.

\section{ACKNOWLEDGEMENTS}

I would like to thank the National Research Foundation, South Africa, for financially supporting this study. Gordon Harkins is sincerely thanked for collecting the specimens. Mary Spencer Jones and Elizabeth Hoenson are thanked for ensuring access to the specimens housed at the Natural History Museum, London, and the Iziko Museums of South Africa. Lastly, I would like to thank my father, Lionel Florence, who passed away during the drafting of this manuscript, for teaching me how to be passionate, committed and persistent.

\section{REFERENCES}

AUDOUIN, J.V. 1826. Explication sommaire des planches de polypes de l'Egypte et de la Syrie, publiées par Jules-César Savigny. Description de l'Egypte 1: 225-244.

BUSK, G. 1852. Catalogue of Marine Polyzoa in the Collection of the British Museum.1. Cheilostomata Vol.pp 1-54. London: Trustees of the British Museum (Natural History).

BUSK, G. 1854. Catalogue of Marine Polyzoa in the Collection of the British Museum. 2. Cheilostomata Vol. pp. 55-120. London: Trustees of the British Museum (Natural History).

BUSK, G. 1884. Report on the Polyzoa collected by H.M.S Challenger during the years 1873-1876. Part 1. The Cheilostomata. Report on the Scientific Results of the Voyage of the H.M.S. "Challenger", Zoology 10: 1-216.

FLORENCE, W.K., HAYWARD, P.J. \& GIBBONS, M.J., 2007. Taxonomy of shallow-water Bryozoa from the west coast of South Africa. African Natural History 3: 1-58.
GABB, W.M. \& HORN, G.H. 1862. The fossil Polyzoa of the secondary and Tertiary formations of North America. Journal of the Academy of Natural Sciences of Philadelphia 5(2): 111-179.

GONTAR, V.I., 1993. New species of Cheilostomida from the Kuril Islands (Bryozoa). Zoosystematica Rossica 1: 9-12

GORDON, D.P. 1984. The marine fauna of New Zealand: Bryozoa: Gymnolaemata from the Kermadec Ridge. New Zealand Oceanographic Institute Memoir 91: 1-198.

GRAY, J.E. 1848. List of the Specimens of British Animals in the Collection of the British Museum. 1. Centroniae or Radiated Animals. 173 pp. London: British Museum.

GRAY, J.E. 1872 On Flustra marginata of Krauss and an allied species, forming a new genus (Flustramorpha) of Escharidae, from Natal. Annals and Magazine of Natural History (4)10: 167-169.

GREGORY, J.W. 1893. On the British Palaeogene Bryozoa. Transactions of the Zoological Society of London 13: 219-279.

HARMER, S.F. 1923. On cellularine and other Polyzoa. Journal of the Linnean Society of London (Zoology) 35: 293-361.

HARMER, S.F. 1957. The Polyzoa of the Siboga expedition. Part 4. Cheilostomata Ascophora. Siboga Expedition Reports 28d: 641-1147.

HASTINGS, A.B. 1943. Polyzoa (Bryozoa) 1. Scrupocellariidae, Epistomiidae, Farciminariidae, Bicelleriellidae, Aeteidae, Scrupariidae. Discovery Report 22: 301-510.

HAYWARD, P.J. 1988. The Recent species of Adeonella (Bryozoa: Cheilostomata) including descriptions of fifteen new species. Zoological Journal of the Linnean Society 94: 111-191.

HAYWARD, P.J. \& COOK, P.L. 1979. The South African Museum's Meiring Naudé Cruises. Part 9, Bryozoa. Annals of the South African Museum 79(4): 43-130.

HAYWARD, P.J. \& COOK, P.L. 1983. The South African Museum's Meiring Naudé Cruises. Part 13, Bryozoa II. Annals of the South African Museum 91: 1-161.

HINCKS, T. 1878. Notes on the genus Retepora, with descriptions of new species. Annals and Magazine of Natural History (5)1: 353-365.

HINCKS, T. 1879. On the classification of the British Polyzoa. Annals and Magazine of Natural History (5)3: 153-164.

HINCKS, T., 1881. Contributions towards a general history of the marine Polyzoa. Part IV. Annals and Magazine of Natural History (5) 7: 147-156.

d'HONDT, J.L. 1985.Contribution à la systématique des Bryozoaires Eurystomes. Apports récents et nouvelles propositions. Annales des Sciences naturelles, Zoologie \& Biologie animale 7: $1-12$.

JULLIEN, J. 1888. Bryozoaires. Mission scientifique du Cap Horn 1882-1883, 6 (Zoologie 3): 1-92.

KLUGE, G.A. 1914. Die Bryozoen der Deutschen SüdpolarExpedition 1901-1903, 1. Die Familien Aetidae, Cellularidae, Bicellaridae, Farciminaridae, Flustridae, Membraniporidae and Cribrilinidae. Deutsche Südpolar-Expedition 15, Zoologie 7(5): 599-678.

KRAUSS, C.F.F., 1837. Beitrag zur Kenntnis der Corallineen und Zoophyten der Südsee nebst Abbildungen der neuen Arten Vol. pp. 1-37. Schweizerbart, Stuttgart.

LAMARCK, J.B.P.A. de. 1816. Histoire naturelle des animaux sans vertèbres 2. 1-568 pp. Paris: Verdière.

LAMOUROUX, J.V.F. 1812. Extrait d'un mémoire sur la classification des Polypiers coralligènes non entièrement pierreux. Nouvelle Bulletin Scientifique de la Société Philosophique, 3: 181-188.

LEVINSEN, G.M.R. 1909. Morphological and Systematic Studies on the Cheilostomatous Bryozoa. Copenhagen: Nationale Forfatteres Forlag.

MACGILLIVRAY, P.H., 1869. Descriptions of some new genera and species of Australian Polyzoa; to which is added a list of species found in Victoria. Transactions and Proceedings of the Royal Society of Victoria 9: 126-148.

MARCUS, E. 1922. Südafrikanische Bryozoen aus der Sammlung des Gothenburger Museums. Göteborgs Kungl Vetenskaps och Vitterhets Samhalles Handlingar 25: 1-45. 
MILNE EDWARDS, H. 1836. Histoire des Polypes. In: LAMARCK, J.B.P.A. de. Histoire naturelle des animaux sans vertébres 2 . Paris. NORMAN, A.M. 1903. Notes of the natural history of East Finmark. Annals and Magazine of Natural History (7)12: 87-128.

O'DONOGHUE, C.H. 1924. The Bryozoa (Polyzoa) collected by the S.A. 'Pickle'. Report on the Fisheries Marine Biological Survey of South Africa 3 Special Report 10: 1-63.

O'DONOGHUE, C.H. 1957. Some South African Bryozoa. Transactions of the Royal Society of South Africa 35: 71-95.

O'DONOGHUE, C.H. \& DE WATTEVILLE, D. 1935. A collection of Bryozoa from South Africa. Journal of the Linnean Society, Zoology 39: 203-218.
O'DONOGHUE, C.H. \& DE WATTEVILLE, D. 1937. Notes on South African Bryozoa. Zoologischer Anzeiger 117: 1222 .

O'DONOGHUE, C.H. \& DE WATTEVILLE, D. 1944. Additional notes on Bryozoa from South Africa. Annals of the Natal Museum 10: $407-432$.

ORBIGNY, A.D. d'. 1851. "Paléontologie française. Description des Mollusques et rayonnés fossiles. Terrains crétacés, V. Bryozoaires.". 188 pp. Paris: Victor Masson.

STACH, L.W. 1936. Studies on Recent Petraliidae (Bryozoa). Records of the Australian Museum 19(6): 355-379. 